\title{
ОСНОВНЫЕ СВЕДЕНИЯ О НАЛОГЕ НА РОСКОШЬ В ЗАРУБЕЖНЫХ СТРАНАХ И ПЕРСПЕКТИВЫ ЕГО ПРИМЕНЕНИЯ В РОССИЙСКОЙ ФЕДЕРАЦИИ
}

\author{
(ㄷ) 2020 Инароков Идар Русланович \\ студент направления «юриспруденция», Институт права, экономики и финансов \\ Кабардино-Балкарский Государственный Университет им. Х. М. Бербекова, Россия, Нальчик \\ E-mail: idar.inarokov98@yandex.ru
}

В статье уделяется внимание попыткам внедрения налога на роскошь в Российской Федерации, учитывая зарубежный опыт аналогичного взимания налога, а также рассматриваются основные проблемы его внедрения. Предполагается, что целью введения налога на роскошь, как самостоятельного вида платежей, должна являться более полная реализация принципа вертикальной справедливости налогообложения. Однако в настоящее время, как показывает исследование, введение полноценного налога на роскошь в Российской Федерации не представляется возможным ввиду ряда причин.

Ключевые слова: налог, налог на роскошь, налогообложение, налогообложение физических лиц, подоходное налогообложение, прогрессивное налогообложение.

Достаточно давно и регулярно в научных, политических и общественных кругах идет обсуждение и рассматривается идея внедрения в Российской Федерации налога на роскошь. Проект по его применению находится в разработке достаточно давно, но при этом регулярно корректируется и откладывается. Правительство страны и по сей день в полной мере не определило, что еще можно причислить к категории «роскошь», в связи с этим в налоговой системе РФ различные элементы налога на роскошь (в понимании практики зарубежных стран) включены в уже существующие налоги на имущество физических лиц и транспортный.

В условиях непростого, в экономическом смысле, прошедшего десятилетия в России поднималось множество вопросов по внесению существенных изменений в функционирующее законодательство. Идея по внедрению налога на роскошь была неоднократно озвучена, по мнению сторонников подобной реформы он способен перенаправить затраты на дорогостоящие покупки лиц, выплачивающих налоги, для улучшения инвестиционного климата страны [1].

Говоря о налоговой политике зарубежных стран следует отметить, что практика взимания налога на роскошь широко распространена. Возьмем опыт таких стран как Франция, Великобритания, Испания - здесь данный налог является своеобразной трансформацией подоходного с той оговоркой, что его налоговая ставка прямым образом зависит от размера доходов налогоплательщика [2].

Отдельно следует рассказать об опыте Франции. До 2018 года в данной стране функционировал налог солидарности на богатство, взимаемый с конкретных категорий граждан. Под богатством понималось не только дорогостоящее имущество, кроме того к данному понятию относились и сумма средств, которая «лежала» на счетах в банке, и величина получаемого дохода. Далее, с 2018 года, данный вид налога был трансформирован в налог на недвижимое имущество, что изменило юридическую трактовку термина «богатство» и с этого момента под ним понимается только недвижимое имущество. Что касается формулы расчета, то она достаточно сложная, так как на сумму платежа влияет не только стоимость недвижимости, но и размер потраченных на ее содержание расходов, которые влияют на объем суммы, которую необходимо выплатить налогоплательщику [1].

Если взять налог на богатство, действующий в Испании, то он рассчитывается относительно просто, так как тут богатыми считаются те, кто владеет на праве собственности имуществом, которое в общей сумме стоит больше 700 тысяч евро [3].

Говоря о Великобритании следует сказать, что здесь существует так называемый гербовый сбор, под которым понимается налог на дорогостоящую недвижимость, уплачиваемый налогоплательщиком при приобретении ее путем покупки. Что касается ставки, то она зависит от 
стоимости покупаемого объекта и составляет от 1 до 5 процентов от его стоимости [4].

Возвращаясь к России, налог на роскошь никогда не входил в структуру системы налогообложения нашей страны. Попытка разработки особого вида налогов для категорий граждан, обладающих дорогостоящим имуществом, впервые была предпринята в 2010 году. Был составлен законопроект, согласно которому было предложено обложить таким налогом участки земли и недвижимость, стоимость которых превышает 15 миллионов рублей. Кроме того, под действие так и не нашедшего отражения в нормативно-правовых актах закона могли попасть и транспортные средства (яхты, самолеты, вертолеты, автомобили) дороже 2 миллионов рублей. Затрагивал данный законопроект и ювелирные украшения, предметы искусства, драгоценные камни и металлы, стоимость которых превышает 300 тысяч рублей. Но, как упомянуто, законопроект был отклонен.

Позже подобная инициатива была предпринята Федеральной налоговой службой в 2013 году, но она не увенчались успехом, так как орган столкнулся с рядом препятствий, заключающимися в определении дорогостоящих видов имущества, которые должны служить объектами обложения. При всем при этом, с 2014 года действует повышенный коэффициент при уплате транспортного налога, в частности, на автомобили, цена которых превышает 3 миллиона рублей, однако данный коэффициент зависит от стоимости транспорта, года его выпуска по принципу чем старее - тем ниже коэффициент оплаты за него [1].

По статистическим данным за период с 2014 по 2019, пока существовал повышенный коэффициент к транспортному налогу, общий объем поступлений вырос до 29,2 миллиардов рублей, что составляет лишь $1,4 \%$ от общего объема налоговых доходов бюджетов субъектов Российской Федерации, 0,07\% от объемов налоговых доходов консолидированного бюджета, что говорит о незначительных пополнениях [4].

После этого и по сей день звучат идеи о расширении данных мер до полноценного налога на роскошь и закреплении его в российском законодательстве. Так, основываясь на теории, под уплату налога могут попасть отдельные объекты культуры и искусства. При этом необходимо отметить, что появляется необходимость разделения облагаемых объектов по региональному признаку, так как стоимость жилья по России отличается друг от друга. Что касается предметов искусства, то возможно применение определенных льгот по уплате налога, но при условии, что данные объекты останутся в стране [5].

Введение элементов налога на роскошь в российской налоговой системе требует серьезного и ответственного подхода. К обязательным требованиям относится четкое определение дефиниций, выделение объектов налогообложения и критериев их определения, отсутствие размытости в формулировках. На текущий момент проект соответствующего федерального закона не опубликован, что усложняет анализ возможностей применения налога.

При всем при этом введение сопряженно с определенным риском, а именно с нанесением ущерба среднему классу или даже полным его уничтожением. Несомненно, введение имущественного налога с целью налогообложения дорогостоящего имущества - достаточно актуальная и востребованная идея. Но важным условием введения подобного налога в российской налоговой системе должно стать предупреждение возможностей уклонения от уплаты налога, повышение эффективности налогового контроля [3].

Впрочем, налог на роскошь не должен иметь исключительную направленность на реализацию фискальной функции государства. Его главной задачей должно стать мотивирование обеспеченных слоев населения на производство общественных благ. Для государства основной задачей будет активное привлечение свободных доходов обеспеченных слоев населения в инвестиции, что, безусловно, увеличит ВВП РФ. Проще говоря, налог на роскошь должен создавать такие условия, при которых богатые граждане будут замотивированы на создание новых социальных условий жизнедеятельности, т.к. это будет приводить к снижения их налоговой нагрузки [4].

Но следует сказать, что введение налога на роскошь отодвинулось все дальше в связи с тем, что в транспортный налог и налог на имущество физических лиц были включены его отдельные элементы. Помимо этого, введение данного вида налогов может привести к некоторым негативным экономическим результатам, таким как возникновение необходимости у налогоплательщиков самостоятельно отчитываться в доходах со всеми административными издерж- 
ками, рост случаев уклонения от уплаты налогов, применение теневых схем, дополнительные административные расходы на внедрение данного проекта в реальность и осуществление контрольных мероприятий, но следует отметить что часть перечисленных проблем существует и обособленно от налога на роскошь в современных реалиях [5].

Следует отметить, что существующий сегодня повышенный налог на имущество ошибочно именуют налогом на роскошь, но это не совсем корректно, так как последний термин не закреплен в нормативно-правовых актах РФ и не используется государством и налоговыми органами. Более того, повышенный налог на имущество регулирует налоговую ставку не только вещей и недвижимости, которые можно было бы назвать роскошью.

На сегодняшний день данная система налогообложения работает следующим образом. Если стоимость недвижимости превышает 300 миллионов рублей, то ежегодный налог на нее рассчитывается по формуле: кадастровая стоимость $\times 0,2$. То есть придется заплатить $2 \%$.

Для домов и квартир меньшей ценности есть градация:

- стоимость до 7 млн. рублей - 1\% от кадастровой стоимости;

- стоимость 7-20 млн. рублей - 1,5\%.

Что касается автомобилей, то сумма с которой на нее начинает действовать повышенный налог на имущество - 3 миллиона рублей, однако следует отметить, что речь идет не о рыночной стоимости, а об условной. Перечень марок и моделей, средняя стоимость которых превыша- ет порог, публикуется Минпромторгом РФ ежегодно, в марте. Таким образом, с точки зрения закона, не важно, за сколько вы купили машину - значение имеет лишь усредненная цена, которая определяется министерством.

Для автомобилей расчет повышенного налога на имущество выглядит следующим образом: величина транспортного налога умножается на мощность (л.с.) и повышающий коэффициент, который будет разным для разных категорий машин из перечня. При средней условной стоимости машины:

- 3-5 млн. руб., 2-3 года с выпуска - коэффициент составляет 1,1 ;

- 3-5 млн. руб., 1-2 года с выпуска - 1,3;

- 3-5 млн. руб., не более года с выпуска - 1,5;

- 5-10 млн. руб., не более 5 лет с выпуска - 2;

- 10-15 млн. руб. (не более 10 лет с выпуска) и более 15 млн. руб. (не более 20 лет с выпуска) $3[6]$.

Таким образом, шансы на включение в Налоговый кодекс РФ закона о полноценном налоге на роскошь в нашей стране на сегодняшний день остаются крайне низкими. Безусловно, данный вид налога соответствует запросам большинства граждан России. Однако Государственной Думе не представляется возможным единовременно скорректировать поддержку и защиту доходов среднего класса при введении данного типа налогов. В целом, внедрение налога на роскошь позволит дестимулировать сверхизбыточное потребление дорогостоящих товаров и создаст условия для инвестиционной деятельности представителей обеспеченных слоев населения.

\section{Библиографический список}

1. Данькина И.А., Клевкова А. С., Савинова О. В. Проблемы налогообложения в России // Символ науки. - 2016. № 11.- С. 45-46.

2. Косенкова Ю.Ю., Турбина Н.М., ЗобоваЕ.В. Социальные и экономические последствия ведения налога на недвижимость физических лиц в Российской Федерации // Социально-экономические явления и процессы.-2016. - Т. 11. № 9.- С. 40-46.

3. Любиченко А.С. Актуальные проблемы налогообложения доходов физических лиц и пути их решения в налоговой системе РФ // Экономика и социум. - 2016. - № 3. - С. 314-320.

4. Рябоконь С. С. Правовое регулирование налога на роскошь в России и других странах // Полиматис. - 2016. № 2.- С. 77-78.

5. Скакунова А. А. Налоговый потенциал страны и регионов: его место и роль в системе налогового регулирования // Экономические и гуманитарные науки. - 2016. - № 1.- С. 57-59.

6. Информационный ресурс. Федеральная налоговая служба РФ. URL: https:/www.nalog.ru/rn77/taxation/ taxes/nnifz/ 